\title{
An Audit of primary ovarian pregnancy in a tertiary care hospital
}

\author{
Sairem Mangolnganbi Chanu' ${ }^{1}$, Biswajit Dey ${ }^{2 *}$, Gourisankar Rudrapal ${ }^{1}$, \\ Subrat Panda ${ }^{1}$, Vandana Raphael ${ }^{2}$, Ahanthem Santa Singh ${ }^{1}$
}

${ }^{1}$ Department of Obstetrics and Gynecology, ${ }^{2}$ Department of Pathology, NEIGRIHMS, Shillong, Meghalaya, India

Received: 06 June 2018

Accepted: 06 June 2018

\section{*Correspondence:}

Dr. Biswajit Dey,

E-mail: drbish25@rediffmail.com

Copyright: (C) the author(s), publisher and licensee Medip Academy. This is an open-access article distributed under the terms of the Creative Commons Attribution Non-Commercial License, which permits unrestricted non-commercial use, distribution, and reproduction in any medium, provided the original work is properly cited.

\section{ABSTRACT}

Background: Ovarian pregnancy is uncommon form of ectopic pregnancy with increasing trend in its incidence. Various risk factors have been implicated like intrauterine contraceptive devices, fertility treatments, pelvic inflammatory disease (PID), and endometriosis.

Methods: This is a retrospective observational study done over a period of 10 years from January 2008 to December 2017.All the patients, who were diagnosed as primary ovarian pregnancy based on Spielberg's criteria, were included in the study.

Results: There were 6 cases $(6.3 \%)$ of primary ovarian pregnancy out of the 95 cases of ectopic pregnancies. The age of the patients ranged from 28 years to 43 years with a mean age of 31.8 years. Amenorrhea and acute pain abdomen was present in all the patients. Laparotomy was done in all the cases. Excision of the sac with partial ovariectomy was done in 2 cases (33.3\%).Oophorectomy with salpingectomy was done in the rest of the 4 cases $(66.7 \%)$. Histopathological confirmation was done in all the cases.

Conclusions: Ovarian pregnancy is uncommon form of ectopic pregnancy with increasing trend in its incidence. Management of choice is laparoscopy. Laparotomy is done if there are signs of rupture.

Keywords: Chorionic villi, Laparoscopy, Ovariectomy, Pregnancy

\section{INTRODUCTION}

Ovarian pregnancy is uncommon form of ectopic pregnancy with an incidence of 1/7000-1/40,000 live births and $0.5-3 \%$ of all ectopic gestations. ${ }^{1,2}$ The etiology is unknown. A possible explanation for the development of ovarian ectopic pregnancies is embryo migration. $^{3}$

Intrauterine contraceptive devices (IUCD) and fertility treatments remain important associated risk factors. Risk factors like previous ectopic pregnancy, pelvic inflammatory disease (PID), and endometriosis have been implicated in the pathogenesis.
These pathologies cause damage to epithelial lining of the fallopian tubes that impairs the normal ovum migration. ${ }^{3}$ The criteria for diagnosis of primary ovarian pregnancy were originally provided by Spielberg in the year $1878 .{ }^{4}$

While the original Spielberg's criteria still hold for the diagnosis, the addition of ultrasonography (USG) scanning has made a radiological diagnosis possible. The actual incidence increases up to 1 in 1400 deliveries if the criteria other than those of Spielberg are taken into consideration. ${ }^{5}$ These criteria combine biochemical and USG findings and include

- Serum $\beta$-human chorionic gonadotropin ( $\beta$-hCG) level $\geq 1000 \mathrm{IU} / \mathrm{L}$. 
- No gestational sac in uterine at transvaginal ultrasound.

- Ovarian involvement should be confirmed on exploration, with bleeding, visualization of chorionic villi or presence of atypical cyst as the ovary.

- Normal tubes

- Absence of serum $\beta$-hCG after treatment of ovary. ${ }^{5}$

There are a few case reports and very few case series on primary ovarian pregnancy. This study was undertaken to study the various clinical parameters of primary ovarian pregnancy and management done in a tertiary care institute.

\section{METHODS}

This is a retrospective observational study done over a period of 10 years from January 2008 to December 2017 in a tertiary care teaching hospital in Northeast India. Clinical details regarding patients' age, parity, presenting symptoms and laterality of the cysts were obtained from hospital records for analysis.

\section{Inclusion criteria}

- All the patients, who were diagnosed as primary ovarian pregnancy based on Spielberg' scriteria, were included in the study.

The Spielberg's criteria include

- The fallopian tube and fimbria should be intact and separate from the ovary.

- The gestational sac should occupy the normal position of the ovary.

- The ovary should be connected to the uterus by ovarian ligament.

- Ovarian tissue must be located in the sac wall, are essential for confirmation of early ovarian pregnancy. 4
In advance pregnancies last criterion i.e., detection of ovarian tissue in the wall of sac may not be satisfied as parenchyma is compressed laminated and distended by developing fetus. ${ }^{4}$

\section{Exclusion criteria}

- The patients, who did not meet the Spielberg's criteria for diagnosis of primary ovarian pregnancy.

This is a retrospective observational study. All data were analyzed by Microsoft excel 2016.

\section{RESULTS}

A total of 5535 deliveries were conducted during the study period. There were 95 cases of ectopic pregnancies $(1.7 \%)$. There were 6 cases $(6.3 \%)$ of primary ovarian pregnancy out of the 95 cases of ectopic pregnancies. The age of the patients ranged from 28 years to 43 years with a mean age of 31.8 years. Amenorrhea and acute pain abdomen was present in all the patients. Three patients (50\%) had vaginal bleeding. Three patients $(50 \%)$ presented with circulatory shock.Two patients $(33.3 \%)$ had history of tubal ligation. Another two (33.3\%) patients had ICUD. One patient was undergoing treatment for infertility. She had undergone intrauterine insemination following ovulation induction. History of PID was present in one patient (Table 1). Left ovary was involved in 1 case only. Excision of the sac with partial ovariectomy was done in 2 cases $(33.3 \%$ ) (Table 1). Medical management with a single dose of methotrexate was offered to one of the patients as the patient was hemodynamically stable. However, on fourth day a decision for laparotomy was taken because of the clinical features of shock.

Table 1: Details of patients of primary ovarian pregnancy.

\begin{tabular}{|c|c|c|c|c|c|}
\hline Age & Parity & Risk factors & Presenting symptoms & Laterality & Intervention \\
\hline 28 & 0 & IUCD & $\begin{array}{l}\text { Amenorrhea } \\
\text { Pain abdomen }\end{array}$ & Right & $\begin{array}{l}\text { Medical management followed by } \\
\text { partial ovariectomy }\end{array}$ \\
\hline 29 & 4 & Previous tubal surgery & $\begin{array}{l}\text { Amenorrhea } \\
\text { Pain abdomen } \\
\text { Bleeding PV, Shock }\end{array}$ & Right & Salpingopherectomy \\
\hline 43 & 3 & Infertility & $\begin{array}{l}\text { Amenorrhea } \\
\text { Pain abdomen } \\
\text { Bleeding PV, Shock }\end{array}$ & Left & Oophorectomy \\
\hline 33 & 2 & IUCD & $\begin{array}{l}\text { Amenorrhea } \\
\text { Pain abdomen } \\
\text { Bleeding PV, Shock }\end{array}$ & Right & Salpingopherectomy \\
\hline 30 & 2 & Previous tubal surgery & $\begin{array}{l}\text { Amenorrhea } \\
\text { Pain abdomen }\end{array}$ & Right & Salpingopherectomy \\
\hline 28 & 1 & PID & $\begin{array}{l}\text { Amenorrhea } \\
\text { Pain abdomen }\end{array}$ & Right & Partial ovariectomy \\
\hline
\end{tabular}


Oophorectomy with salpingectomy was done in the rest of the 4 cases $(66.7 \%)$. Histopathological examination was done in all the cases. Histopathological examination showed chorionic villi within ovarian stroma and surrounding hemorrhage, thus confirming the diagnosis of ovarian pregnancy (Figure 1).

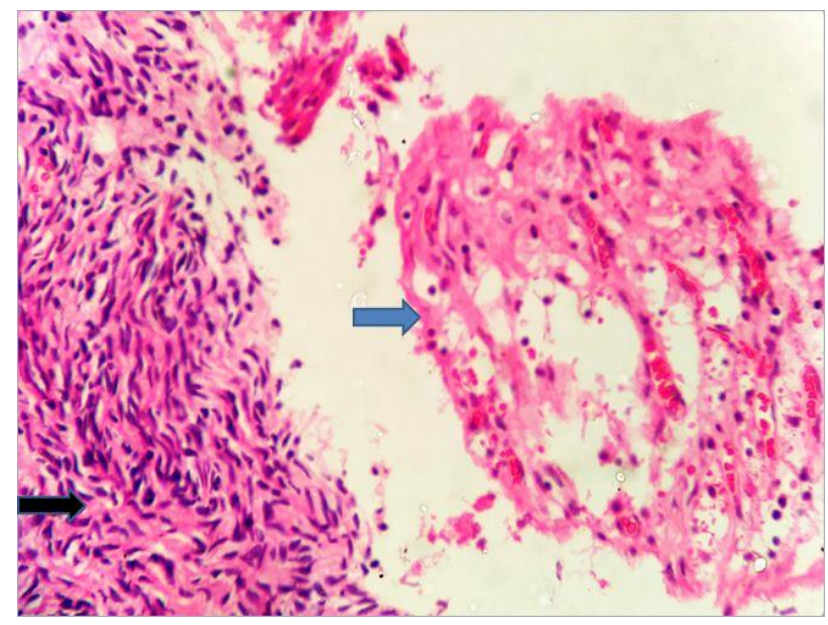

Figure 1: Histopathology showing chorionic villi (blue arrow) embedded within ovarian parenchyma (black arrow). (H and E, 400x).

The post-operative period is unremarkable in all the cases with negative pregnancy test.

\section{DISCUSSION}

The incidence of ovarian pregnancy is $0.5-3 \%$ of all ectopic gestations. ${ }^{1,2}$ However, there has been a rise in the incidence of ovarian pregnancy. ${ }^{2}$ In present study, the incidence was $6.3 \%$ of all ectopic pregnancies. High prevalence of sexually transmitted disease and PID, IUCD and assisted reproductive techniques are some of the causative factors attributed to increased incidence of ectopic gestations. ${ }^{2,3}$ Increased availability of diagnostic facilities has led to increased documentations of such cases. ${ }^{2}$ In the present study, known risk factors like PID, and assisted reproductive technique were present in one patient each.

Literatures suggest that the cases of ovarian pregnancy after assisted reproductive techniques like in-vitro fertilization support the theory of reflux. ${ }^{6,7}$ Etiopathogenesis of ovarian pregnancy in such scenarios is due the fertilization of the ovum inside the ovary or implantation of the fertilized ovum in the ovary. ${ }^{6,7}$ IUCD was present in two patients. IUCD is known to prevent intrauterine but not extra uterine pregnancies. ${ }^{2}$ It is hypothesized that IUCD increases tubal peristalsis due to imbalance in the synthesis of prostaglandin leading to ovarian nidation. ${ }^{8}$

In the present study, there were 2 cases of ovarian pregnancy with previous history of tubal ligation. Ectopic gestation following tubal ligation is attributed to recanalization or formation of a tuboperitoneal fistula. ${ }^{9}$ In such scenarios, implantation occurs in the distal tubal segment as spermatozoa may go through, but the fertilized ovum fails to pass through. ${ }^{9,10}$ There are few case reports of ovarian ectopic pregnancy following postpartum sterilization., ${ }^{9,11}$ Following postpartum sterilization, the tubes are edematous, friable and congested, which results in incomplete occlusion of tubal lumen ultimately leading to ovarian ectopic. ${ }^{9,11}$

Majority of the ovarian pregnancy rupture in the first trimester and very rarely it may lead to term pregnancy. ${ }^{2}$ In the present study, 4 cases presented with rupture with hemoperitoneum.

Pre-operative diagnosis may be difficult as most of the patients present late with clinical features of shock. ${ }^{2}$ Transvaginal USG and serum $\beta$-hCG are important aid to pre-operative diagnosis. ${ }^{2}$ However, ovarian tumour secreting hCG may delay the diagnosis. ${ }^{2}$ Intraoperative diagnosis is equally difficult because it may mimic a hemorrhagic corpus luteal cyst. ${ }^{12}$ Therefore, histopathological confirmation is important. ${ }^{13}$ Histopathology shows chorionic villi embedded in the ovarian parenchymal tissue. ${ }^{9}$ All the cases in the present study had histopathological confirmation.

A partial laparoscopic oophorectomy or wedge resection at laparotomy is appropriate if no other ovarian pathology is present in the ipsilateral ovary. ${ }^{3}$ Absence of excessive bleeding also justifies similar management. ${ }^{3}$ Laparotomy is preferred if there is rupture with co-existent haemoperitoneum. ${ }^{3}$ As there is no risk of recurrence in ovarian ectopic pregnancy, the aim of such surgical management is to remove the ectopic pregnancy, while preserving the ovarian tissue. ${ }^{14}$ In the present study, oophorectomy had to be performed in 4 cases because of uncontrolled hemorrhage.

There have been few reported attempts to treat ovarian pregnancy using medical management. ${ }^{15}$ Methotrexate and etoposide have been used as an alternative to surgery with various success rates. ${ }^{3,15}$ In the present study, one of the cases was initially managed by medical treatment, however laparotomy has to be performed after fourth day due to features of shock. Postoperative use of methotrexate is indicated in the presence of persistent residual trophoblast or persistently raised hCG levels. ${ }^{15}$

To summarize the incidence of primary ovarian pregnancy is on the rise. Laparoscopic surgery is the management of choice however, laparotomy is preferred if there is rupture with co-existent haemoperitoneum. Histopathological examination should be done for confirmation.

\section{Funding: No funding sources}

Conflict of interest: None declared

Ethical approval: The study was approved by the Institutional Ethics Committee 


\section{REFERENCES}

1. Raziel A, Golan A, Pansky M, Ron-El R, Bukovsky I, Caspi E. Ovarian pregnancy: A report of twenty cases in one institution. Am J Obstet Gynecol. 1990; 163:1182-5.

2. Goyal LD, Tondon R, Goel P, Sehgal A. Ovarian ectopic pregnancy: A 10 years' experience and review of literature. Iran $\mathbf{J}$ Reprod Med. 2014;12:825-30.

3. Joseph RJ, Irvine LM. Ovarian ectopic pregnanacy: aetiology, diagnosis, and challenges in surgical management. J Obstet Gynaecol. 2012;32:472-4.

4. Spigelberg O. Casusistik der ovarialschwangerschaft. Arch Gynecol. 1878;13:73.

5. Sergent F, Mauger-Tinlot F, Gravier A, Verspyck E, Marpean L. Ovarian pregnancies: revaluation of diagnostic criteria. J Gynecol Obstet Biol Reprod. 2002;31:741-6.

6. Ramachandran A, Sharma S, Pratap K, Rajesh B, Akhila V, Ramayapally A, et al. Ovarian pregnancy following intracytoplasmic Sperm injection and embryo transfer: A case report. Case Rep Obstet Gynecol. 2012;2012:389107.

7. Ashrafganjoei T, Honer BN, Dafaee S. Thirteen weeks ovarian pregnancy following in vitro fertilization for primary infertility treatment: A case report. Iran J Reprod Med. 2014;12:779-84.

8. Reichman J, Goldman JA, Feldberg D. Ovarian Pregnancy: Association with IUD, Pelvic pathology and recurrent abortion. Eur J Obstet Gynecol Reprod Biol. 1981;12:333-7.
9. Vahnu C, Rajlaxmi M, Raphael V. Primary ovarian pregnancy after interval tubal ligation: a case report. J Family Reprod Health 2013;7:187-8.

10. Davis MR. Recurrent ectopic pregnancy after tubal sterilization. Obstet Gynecol. 1986;68:44S-5S.

11. Wittich AC. Primary Ovarian Pregnancy after postpartum bilateral tubal ligation: a case report. J Reprod Med. 2004,49:759-61.

12. Hallatt JG. Primary ovarian pregnancy: a report of twenty-five cases. Am J Obstet Gynecol. 1982;143:55-60.

13. Anand P, Nargotra N. Primary ovarian pregnancy: histopathology remains the key to confirming diagnosis setting. Int $\mathbf{J}$ Reprod Contracept Obstet Gynecol. 2017;6:1649-51.

14. Odejinmi F, Rizzuto MI, Macrae R, Olowu O, Hussain M. Diagnosis and laparoscopic management of 12 consecutive cases of ovarian pregnancy and review of literature. J Minim Invasive Gynecol. 2009;16:354-9.

15. Mittal S, Dadhwal V, Baurasi P. Successful medical management of ovarian Mittal S, Dadhwal V, Baurasi P. Successful medical management of ovarian pregnancy. Int $\mathrm{J}$ Gynecol Obstet. 2003;80:309-10.

Cite this article as: Chanu SM, Dey B, Rudrapal G, Panda S, Raphael V, Singh AS. An Audit of primary ovarian pregnancy in a tertiary care hospital. Int $\mathbf{J}$ Reprod Contracept Obstet Gynecol 2018;7:3316-9. 